\title{
ANALISIS KESULITAN SISWA DALAM MEMECAHKAN SOAL FISIKA PADA MATERI LISTRIK STATIS DI SMP NEGERI 1 TUMPAAN DI ERA COVID-19
}

\author{
Egha Savitri Dali, Treesje Katrina Londa, Alfrits Komansilan \\ Fakultas Matematika dan Ilmu Pengetahuan Alam, Universitas Negeri Manado \\ email: eghadali@gmail.com
}

\begin{abstract}
ABSTRAK
Penelitian ini bertujuan untuk mendeskripsikan kesulitan siswa dalam mememcahkan soal fisika pada materi listrik statis dan mendeskripsikan faktor-faktor penyebab kesulitan siswa. Penelitian ini menggunakan metode kualitatif deksriptif. Subjek penelitian ini yaitu siswa kelas IXB SMP Negeri 1 Tumpaan. Teknik pengumpulan data dalam penelitian ini menggunakan soal tes, wawancara dan dokumentasi. Teknik analisis data dalam penelitian ini menggunakan model Miles dan Huberman meliputi reduksi data, penyejian data, penarikan kesimpulan. Hasil penelitian menunjukkan presentase rata-rata kesulitan siswa dalam memecahkan soal fisika pada materi listrik statis menurut tahapan pemecahan masalah Polya, yaitu: (1) Tahap Memahami Masalah sebesar $76,66 \%$. Penyebabnya adalah siswa lupa dan tidak memahami maksud dari soal (2) Tahap Perencanaan Penyelesian Masalah sebesar 78,66 \%. Penyebabnya adalah siswa tidak tahu persamaan yang harus digunakan. (3) Tahap Melaksanakan Perencanaan Penyelesaian Masalah sebesar 84,66 \%. Penyebabnya adalah Karena siswa tidak tahu persamaan yang harus digunakan, hal ini menyebabkan siswa kesulitan pada tahap melaksanakan rencana dan Siswa kurang terampil dalam melakukan perhitungan (4) Tahap Meninjau Kembali sebesar $90 \%$. Penyebabnya adalah siswa kurang teliti dan tidak memeriksa kembali jawabnnya.
\end{abstract}

Kata kunci : analisis kesulitan, pemecahan masalah, listrik statis

\begin{abstract}
This study aims to describe students 'difficulties in solving physical problems on static electricity and to describe the factors that cause students' difficulties. This research uses descriptive qualitative method. The subjects of this study were class IXB SMP Negeri 1 Tumpaan. The data collection techniques in this study used test questions, interviews, and documentation. The data analysis technique in this study used the Miles and Huberman models, including data reduction, data testing, and inference. The results showed that the average percentage of difficulty students had in solving physical problems with static electricity material according to Polya's Problem Solving Levels: (1) Problem phase understanding was 76.66\%. The reason for this is that the students forget and do not understand the meaning of the questions. (2) The planning phase for problem solving is $78.66 \%$. The reason is that students don't know which equation to use. (3) Phase of implementation of problem-solving planning of $84.66 \%$. The reason for this is that students don't know which equation to use. This results in the students having difficulty in the implementation phase of the plan and less able to do calculations. (4) The review phase is $90 \%$. The reason is that the students are not thorough and do not double-check their answers.
\end{abstract}

Keywords : analysis difficulty, problem Solving, static electricity 


\section{PENDAHULUAN}

Fisika merupakan bidang ilmu pengetahuan alam yang bertujuan untuk mengembangkan kemampuan analisis, pemahaman, dan pengetahuan siswa terhadap lingkungan sekitarnya (Azizah dkk, 2015). Fisika juga merupakan mata pelajaran yang memuat banyak konsep yang bersifat abstrak, sehingga untuk bejajar fisika biasanya melibatkan semua indera yang dimiliki.

Kesulitan belajar dapat diartikan sebagai kemampuan siswa dalam menyelesaikan tugas yang diberikan oleh guru. Fisika dianggap sebagai mata pelajaran paling sulit oleh sebagian siswa dibandingkan dengan mata pelajaran lainnya. Ada beberapa alasan yang menyebabkan fisika menjadi pelajaran yang sulit dimengerti dan diminati siswa. Alasanalasan tersebut yaitu: (1) siswa merasa bahwa fisika itu sulit dan bersifat abstrak, (2) suasana mengajar yang buruk dan tidak adanya media yang membantu proses pembelajaran fisika, serta kebanyakan guru tidak menggunakan variasi metode pembelajaran, (3) kemampuan matematis siswa yang buruk (Adegoke, 2011).

Pemecahan masalah adalah suatu cara agar dapat membantu menyelesaikan kesulitan yang dihadapi oleh siswa dalam memecahkan soal. Kemampuan pemecahan masalah merupakan hal yang disoroti dalam belajar siswa (Datur dkk, 2016). Kemampuan menyelesaikan masalah fisika tidak hanya dibutuhkan oleh siswa di sekolah, tetapi juga di berbagai profesi (Saputri dan Wilujeng, 2017). Dalam memecahkan soal fisika seringkali menggunakan perhitungan matematis sebagai konsekuensi penggunaan rumus-rumus fisika. Pemecahan fisika secara efektif menuntut peserta didik untuk mengidentifikasi, menentukan dan memecahkan masalah menggunakan logika, pemikiran literan dan kreatif (Hedge dan Meera, 2012). Inilah yang menimbulkan kesulitan dalam menyelesaikan soal dikarenakan kemampuan dasar matematika siswa masih kurang dan terbatasnya waktu belajar siswa di kelas. Kurangnya pemahaman konsep fisika juga menjadi salah satu alasan mengapa siswa sulit memecahkan soal.

Dalam menyelesaikan soal fisika diperlukan langkah-langkah yang sistematis agar dalam menyelesaikannya mudah dan terarah. Sejalan dengan hal ini, salah satu teori pemecahan maslah yaitu Polya yang merupakan langkah-langkah penyelesaian suatu masalah yang sistematis. George Polya menyajikan teknik pemecahan masalah yang tidak hanya menarik tetapi juga dapat meyakinkan konsep-konsep yang dipelajari selama proses belajar. Menurut Suherman pemecahan masalah menurut Polya mencakup (1) memahami masalah, (2) perencanaan penyelesaian masalah, (3) melaksanakan perencanaan penyelesaian masalah, (4) meninjau kembali (Rohmah dkk, 2018). Keempat langkah yang dikemukakan Polya memungkinkan terlaksananya penyelesaian masalah yang sistematis dan membangun pola pikir yang terstruktur dengan baik pada diri siswa ketika menghadapi masalah yang akan diselesaikan.

Pokok bahasan listrik statis terdiri dari beberapa sub pokok bahasan antara lain muatan listrik, hukum coulomb, medan listrik, beda potensial dan energi listrik. Pembelajaran fisika pada pokok bahasan tersebut banyak berhubungan dengan kegiatan kehidupan sehari-hari. Oleh karena itu guru harus membuat suatu evaluasi yang baik, yang mampu mengukur kemampuan siswa dalam menyelesaikan masalah secara sistematis. Guru cenderung memberikan soal tes yang belum tentu bisa mengevaluasi kemampuan siswa dalam memahami masalah, perencanaan suatu strategi, dan pelaksanaan strategi itu sendiri.

Namun lebih dari setahun ini dunia digemparkan dengan mewabahnya virus yang sangat berbahaya yaitu virus corona atau Covid-19. Penyebaran virus corona di Indonesia memberikan dampak secara tidak langsung untuk negara khususnya sektor pendidikan apalagi sejak diberlakunya Sosial Distancing. Pandemi Covid-19 mengganggu proses pembelajaran secara konvensional.

Salah satu sekolah yang merasakan dampak dari pandemi Covid-19 adalah SMP Negeri 1 Tumpaan. Proses pembelajaran di SMP Negeri 1 Tumpaan dilakukan secara luring dimana proses pembelajaran mematuhi protokol kesehatan. Pembelajaran luar jaringan (luring) mengakibatkan kesulitan khususnya bagi siswa dikarenakan alokasi waktu untuk pemebelajaran sedikit sedangkan materi yang harus disampaikan banyak aktivitas belajar mengajar pun terganggu. Akibatnya guru sering mendapati siswa yang mengalami kesulitan belajar. Kesulitan yang sering dialami siswa 
adalah kesulitan dalam mempelajari konsep yang bersifat abstrak, perhitungan secara matematik dan pemecahan soal. Kebanyakan siswa bekerja kurang sistematis dan kurang memperhatikan langkah-langkah penyeleaiannya. Mereka hanya mementingkan hasil jawaban akhir, sehingga banyak langkahlangkah yang dilewati, padahal hal tersebut merupakan langkah yang menentukan hasil akhir jawaban. Selain kesulitan-kesulitan tersebut, tidak menutup kemungkinan masih terdapat kesulitan-kesulitan yang lain yang dilakukan oleh siswa tersebut.

\section{METODE PENELITIAN}

Metode yang diguakan dalam penelitian ini ialah metode deskriptif. Penelitian ini dilakukan pada 15 siswa kelas IX SMP Negeri 1 Tumpaan yang diambil menggunakan teknik simple random sampling. Instrument pengumpulan data dalam penelitian ini berupa soal tes dan wawancara. Tes yang digunakan dalam penelitian ini yaitu tes essay berjumlah 10 soal. Tes digunakan untuk mengetahui kesulitan siswa dalam memecahkan soal. Wawancara dilakukan pada siswa yang memiliki kemampuan tinggi, sedang dan rendah untuk mengetahui penyebab kesulitan siswa. Teknik analisis data dalam penelitian ini menggunakan model Miles dan Huberman meliputi reduksi data, penyajian data dan penarikan kesimpulan.

Prosedur dalam penelitian ini terdiri dari 3 tahap yaitu: 1) Tahap perencanaan, 2) Tahap pelaksanaan, dan 3) Tahap akhir.

\section{Tahap Perencanaan}

Pada tahap ini akan dilakukan kegiatankegiatan antara lain: (1) Menyusun proposal penelitian; (2) Menyusun instrument penelitian yaitu soal tes dan pedoman wawancara; dan (3) Melakukan validasi terhadap instrument penelitian.

\section{Tahap Pelaksanaan}

Kegiatan yang dilakukan pada tahap pelaksanaan antara lain: (1) Memilih kelas yang akan diteliti; (2) Memberikan soal tes kepada subjek penelitian yang telah ditetapkan; (3) Menganalisis jawaban siswa; dan (4) Melakukan wawancara terhadap subjek penelitian yaitu 6 orang yang terdiri dari siswa yang memiliki kemampuan tinggi, sedang dan rendah.

\section{Tahap Akhir}

Kegiatan yang dilakukan pada tahap akhir antara lain: (1) Menganalisis hasil tes tertulis dan hasil wawancara; (2) Mendeskripsikan hasil penelitian dan menarik kesimpulan; dan (3) Menyusun laporan

\section{HASIL DAN PEMBAHASAN Hasil}

Penelitian ini dilakukan terhadap siswa SMP Negeri 1 Tumpaan yang telah mempelajari materi listrik statis.

Penelitian ini bertujuan untuk mendeskripsikan kesulitan siswa dalam memecahkan soal fisika dan faktor penyebabnya pada materi listrik statis. Berdasarkan hasil tes yang diberikan diperoleh hasil rekaptulasi presentase kesulitan siswa dalam memecahkan soal fisika pada materi listrik statis yang dapat dilihat pada Tabel 1 .

Tabel 1. Rekaptulasi Presentase (\%) Kesulitan siswa dalam Memecahkan Soal Fisika pada Materi Listrik Statis

\begin{tabular}{|c|c|c|c|c|c|c|c|c|c|c|c|}
\hline \multirow{2}{*}{$\begin{array}{c}\text { Kesulitan Menurut } \\
\text { Tahapan Polya }\end{array}$} & \multicolumn{10}{|c|}{ Presentase Tiap Soal } & \multirow{2}{*}{$\begin{array}{l}\text { Rata-Rata } \\
\text { Presentase }\end{array}$} \\
\hline & 1 & 2 & 3 & 4 & 5 & 6 & 7 & 8 & 9 & 10 & \\
\hline \multirow{2}{*}{$\begin{array}{c}\text { Memahami } \\
\text { Masalah }\end{array}$} & $6,67 \%$ & $100 \%$ & $86,67 \%$ & $100 \%$ & $93,33 \%$ & $60 \%$ & $73,33 \%$ & $86,67 \%$ & $80 \%$ & $100 \%$ & $78,66 \%$ \\
\hline & $40 \%$ & $100 \%$ & $86,67 \%$ & $100 \%$ & $100 \%$ & $60 \%$ & $86,67 \%$ & $86,67 \%$ & $80 \%$ & $100 \%$ & $84 \%$ \\
\hline $\begin{array}{c}\text { Perencanaan } \\
\text { Penyelesaian Masalah }\end{array}$ & $0 \%$ & $60 \%$ & $93,33 \%$ & $100 \%$ & $100 \%$ & $60 \%$ & $93,33 \%$ & $100 \%$ & $80 \%$ & $100 \%$ & $78,66 \%$ \\
\hline $\begin{array}{c}\text { Melaksanakan } \\
\text { Perencanaan } \\
\text { Penyelesaian Masalah }\end{array}$ & $13,3 \%$ & $100 \%$ & $100 \%$ & $100 \%$ & $100 \%$ & $60 \%$ & $93,33 \%$ & $100 \%$ & $80 \%$ & $100 \%$ & $84,66 \%$ \\
\hline Meninjau Kembali & $40 \%$ & $100 \%$ & $100 \%$ & $100 \%$ & $100 \%$ & $80 \%$ & $93,33 \%$ & $100 \%$ & $86,67 \%$ & $100 \%$ & $90 \%$ \\
\hline $\begin{array}{l}\text { Rata-Rata } \\
\text { Presentase }\end{array}$ & $20 \%$ & $92 \%$ & $93,33 \%$ & $100 \%$ & $98,66 \%$ & $64 \%$ & $88 \%$ & $94,66 \%$ & $81,33 \%$ & $100 \%$ & $83,2 \%$ \\
\hline
\end{tabular}


Ket:

$1=$ Siswa tidak menulis data yang diketahui secara lengkap

$2=$ Siswa tidak menulis apa yang ditanyakan secara lengkap

Berdasarkan Tabel 1. diketahui rata-rata keseluruhan presentase kesulitan yang dialami oleh siswa dalam memecahkan soal fisika pada materi listrik statis berdasarkan tahapan Polya pada tahap memahami masalah yaitu siswa tidak menulis data yang diketahiu secara lengkap sebesar 76,66 \% dan siswa tidak menulis yang ditanyakan pada soal sebesar 84 $\%$. Rata-rata presentase kesulitan yang dialami siswa pada tahap perencanaan penyelesian masalah sebesar 78,66 \%. Rata-rata presentase tahap melaksanakan perencanaan penyelesaian masalah sebesar $84,66 \%$. Rata-rata presentase tahap meninjau kembali sebesar $90 \%$ yang merupakan presentase tertinggi diantara tahapan lain.

Faktor-faktor yang menyebabkan siswa mengalami kesulitan ketika memecahkan soal fisika materi listrik lain dalam penelitian ini, antara lain dapat dilihat pada Tabel 2.

Tabel 2. Faktor Penyebab Kesulitan Siswa

\begin{tabular}{|c|c|c|}
\hline Subjek & Kesulitan & $\begin{array}{c}\text { Faktor } \\
\text { Penyebab }\end{array}$ \\
\hline 1 & 2 & 3 \\
\hline \multirow[t]{2}{*}{1} & $\begin{array}{l}\text { Memahami } \\
\text { Masalah }\end{array}$ & $\begin{array}{l}\text { Lupa, tidak } \\
\text { mengerti }\end{array}$ \\
\hline & $\begin{array}{l}\text { Perencanaan } \\
\text { Penyelesaian } \\
\text { Masalah }\end{array}$ & $\begin{array}{l}\text { Tidak tahu } \\
\text { rumus, tidak } \\
\text { mengerti }\end{array}$ \\
\hline \multirow[t]{3}{*}{1} & 2 & 3 \\
\hline & $\begin{array}{l}\text { Melaksanakan } \\
\text { Perencanaan } \\
\text { Penyelesaian } \\
\text { Masalah }\end{array}$ & $\begin{array}{l}\text { Tidak tahu } \\
\text { menghitung }\end{array}$ \\
\hline & $\begin{array}{l}\text { Meninjau } \\
\text { Kembali }\end{array}$ & Kurang teliti \\
\hline \multirow[t]{4}{*}{2} & $\begin{array}{l}\text { Memahami } \\
\text { Masalah }\end{array}$ & $\begin{array}{l}\text { Tidak mengerti, } \\
\text { lupa }\end{array}$ \\
\hline & $\begin{array}{l}\text { Perencanaan } \\
\text { Penyelesaian } \\
\text { Masalah } \\
\end{array}$ & $\begin{array}{l}\text { Tidak mengerti, } \\
\text { tidak tahu } \\
\text { rumus }\end{array}$ \\
\hline & $\begin{array}{l}\text { Melaksanakan } \\
\text { Perencanaan } \\
\text { Penyelesaian } \\
\text { Masalah }\end{array}$ & $\begin{array}{l}\text { Tidak teliti } \\
\text { mengitung }\end{array}$ \\
\hline & $\begin{array}{l}\text { Meninjau } \\
\text { Kembali }\end{array}$ & $\begin{array}{l}\text { Tidak terbiasa, } \\
\text { merasa jawaban } \\
\text { sudah benar }\end{array}$ \\
\hline \multirow[t]{2}{*}{3} & $\begin{array}{l}\text { Memahami } \\
\text { Masalah }\end{array}$ & \\
\hline & $\begin{array}{l}\text { Perencanaan } \\
\text { Penyelesaian } \\
\text { Masalah } \\
\end{array}$ & $\begin{array}{l}\text { Tidak tahu } \\
\text { menghitung, } \\
\text { tidak mengerti }\end{array}$ \\
\hline
\end{tabular}

\begin{tabular}{|c|c|c|}
\hline & $\begin{array}{l}\text { Melaksanakan } \\
\text { Perencanaan } \\
\text { Penyelesaian } \\
\text { Masalah }\end{array}$ & $\begin{array}{l}\text { Tidak tahu } \\
\text { rumus }\end{array}$ \\
\hline & $\begin{array}{l}\text { Meninjau } \\
\text { Kembali }\end{array}$ & $\begin{array}{l}\text { Tidak } \\
\text { memeriksa } \\
\text { jawaban }\end{array}$ \\
\hline \multirow[t]{2}{*}{4} & $\begin{array}{l}\text { Memahami } \\
\text { Masalah }\end{array}$ & Tidak mengerti \\
\hline & $\begin{array}{l}\text { Perencanaan } \\
\text { Penyelesaian } \\
\text { Masalah }\end{array}$ & $\begin{array}{l}\text { Tidak tahu } \\
\text { rumus }\end{array}$ \\
\hline \multirow[t]{3}{*}{1} & 2 & 3 \\
\hline & $\begin{array}{l}\text { Melaksanakan } \\
\text { Perencanaan } \\
\text { Penyelesaian } \\
\text { Masalah }\end{array}$ & $\begin{array}{l}\text { Tidak } \\
\text { melakukan } \\
\text { perhitungan }\end{array}$ \\
\hline & $\begin{array}{l}\text { Meninjau } \\
\text { Kembali }\end{array}$ & $\begin{array}{l}\text { Tidak } \\
\text { memeriksa } \\
\text { jawaban }\end{array}$ \\
\hline \multirow[t]{4}{*}{5} & $\begin{array}{l}\text { Memahami } \\
\text { Masalah }\end{array}$ & Tidak mengerti \\
\hline & $\begin{array}{l}\text { Perencanaan } \\
\text { Penyelesaian } \\
\text { Masalah }\end{array}$ & $\begin{array}{l}\text { Tidak tahu } \\
\text { rumus }\end{array}$ \\
\hline & $\begin{array}{l}\text { Melaksanakan } \\
\text { Perencanaan } \\
\text { Penyelesaian } \\
\text { Masalah }\end{array}$ & $\begin{array}{l}\text { Tidak } \\
\text { melakukan } \\
\text { perhitungan }\end{array}$ \\
\hline & $\begin{array}{l}\text { Meninjau } \\
\text { Kembali }\end{array}$ & $\begin{array}{l}\text { tidak } \\
\text { memeriksa } \\
\text { jawaban }\end{array}$ \\
\hline \multirow[t]{4}{*}{6} & $\begin{array}{l}\text { Memahami } \\
\text { Masalah }\end{array}$ & Tidak mengerti \\
\hline & $\begin{array}{l}\text { Perencanaan } \\
\text { Penyelesaian } \\
\text { Masalah }\end{array}$ & $\begin{array}{l}\text { Tidak tahu } \\
\text { rumus }\end{array}$ \\
\hline & $\begin{array}{l}\text { Melaksanakan } \\
\text { Perencanaan } \\
\text { Penyelesaian } \\
\text { Masalah }\end{array}$ & $\begin{array}{l}\text { Tidak } \\
\text { melakukan } \\
\text { perhitungan }\end{array}$ \\
\hline & $\begin{array}{l}\text { Meninjau } \\
\text { Kembali }\end{array}$ & $\begin{array}{l}\text { Tidak } \\
\text { memeriksa } \\
\text { jawaban }\end{array}$ \\
\hline
\end{tabular}

\section{Pembahasan}

Berdasarkan hasil penelitian yang telah diuraikan di atas, diperoleh sebagian besar siswa masih mengalami kesulitan dalam memecahkan soal fisika pada materi listrik statis. Beberapa kesulitan yang dialami siswa dapat diketahui setelah soal diberikan dan dianalisis. 
Berdasarkan data hasil penelitian pada tabel 1. diketahui rata-rata keseluruhan presentase kesulitan yang dialami oleh siswa dalam memecahkan soal fisika pada materi listrik statis berdasarkan tahapan Polya pada tahap memahami masalah yaitu sebesar 76,66 $\%$ siswa tidak menulis data yang diketahiu secara lengkap dan $84 \%$ siswa tidak menulis yang ditanyakan pada soal. Hal ini menunjukan bahwa sebagian besar siswa tidak lengkap dalam menuliskan apa yang diketahui dan ditanya pada soal.

Rata-rata presentase tahap kesulitan yang dialami siswa pada tahap perencanaan penyelesian masalah sebesar 78,66 \% siswa. Hal ini menunjukan bahwa sebagian besar siswa tidak tahu cara atau persamaaan yang harus digunakan pada soal.

Rata-rata presentase tahap melaksanakan perencanaan penyelesaian masalah sebesar $84,66 \%$ siswa. Karena siswa tidak tahu persamaan yang harus digunakan mengakibatkan masalah yang diberikan tidak terselesaikan dengan baik dan tepat.

Rata-rata presentase tahap meninjau kembali sebesar $90 \%$ siswa yang merupakan presentase tertinggi diantara tahapan lain. Dalam penelitian Gumilang dkk (2016) menunjukkan bahwa tahap Polya yang jarang digunakan siswa adalah tahap keempat yaitu memeriksa kembali. Pada tahap ini siswa yang berhasil menjawab soal ada yang memeriksa kembali hasil jawaban yang telah ia buat dan ada yang tidak. Namun sebagian besar siswa tidak menjawab dan tidak menyelesaikan soal sehingga tidak ada peninjauan kembali pada jawabannya.

Dari hasil wawancara yang telah dilakukan pada 6 responden didapatkan faktor penyebab kesulitan siswa dalam memecahkan soal fisika pada materi listrik statis yaitu pada tahap memahami masalah adalah siswa lupa dan tidak memahami maksud dari soal. Faktor penyebab kesulitan siswa dalam tahap perencanaan penyelesaian masalah adalah karena siswa tidak tahu persamaan atau rumus yang harus digunakan. Faktor penyebab kesulitan siswa dalam tahap melaksanakan perencanaan penyelesaian masalah adalah karena siswa tidak tahu persamaan yang harus digunakan menyebabkan siswa kesulitan pada tahap melaksanakan rencana. Selain itu siswa kurang terampil dalam melakukan perhitungan. Faktor penyebab kesulitan siswa dalam tahap meninjau kembali adalah karena siswa kurang teliti dan tidak memeriksa kembali jawabannya.

Berdasarkan Tabel 1. presentase terbesar tahap memahami masalah, merencanakan penyelesaian masalah, melaksanakan perencanaan penyelesaian masalah dan meninjau kembali terdapat pada soal nomor 4 dan 10 sebesar $100 \%$. Hal ini menunjukkan bahwa seluruh siswa mengalami kesulitan menjawab soal pada nomor 4 dan 10 . Sedangkan presentase terkecil tahap memahami masalah terdapat pada soal nomor 1 yaitu $6,67 \%$ dan $40 \%$, tahap merencanakan penyelesaian masalah terdapat pada soal nomor 1 sebesar $0 \%$, melaksanakan perencanaan penyelesaian masalah terdapat pada nomor 1 sebesar 13,33\% dan tahap meninjau kembali terdapat pada soal nomor 1 sebesar $40 \%$.

Faktor penyebab lainnya diduga karena metode belajar guru yang kurang baik sehingga siswa mengalami kesulitan, perhatian guru yang kurang terhadap siswa yang mengalami kesulitan, relasi antar siswa yang kurang baik di dalam membantu siswa lainnya yang mengalami kesulitan, sarana dan prasarana di sekolah yang kurang menunjang kegiatan belajar di dalam kelas serta alokasi waktu belajar siswa yang kurang optimal di era Covid19.

\section{KESIMPULAN}

Berdasarkan analisis data dan pembahasan, masih banyak siswa yang mengalami kesulitan dalam menyelesaikan soal fisika materi listrik statis di SMP Negeri 1 Tumpaan. Secara khusus kesimpulan dalam penelitian ini adalah: (1) Berdasarkan data yang diperoleh, terdapat kesulitan yang dialami siswa dalam memecahkan soal fisika materi listrik statis yaitu: pada tahap memahami masalah siswa mengalami kesulitan sebesar $76,66 \%$, tahap perencanaan penyelesian masalah siswa mengalami kesulitan sebesar 78,66 , tahap melaksanakan perencanaan penyelesaian masalah siswa mengalami kesulitan sebesar 84,66 \%, dan pada tahap meninjau kembali siswa mengalami kesulitan sebesar $90 \%$ yang merupakan presentase tertinggi diantara tahapan yang lain; (2) Faktorfaktor yang menyebabakan siswa kesulitan dalam memecahkan Soal fisika materi listrik statis dalam penelitian ini, yaitu: pada tahap memahami masalah adalah siswa lupa dan tidak memahami maksud dari soal. Faktor 
penyebab kesulitan siswa dalam tahap perencanaan penyelesaian masalah adalah karena siswa tidak tahu persamaan atau rumus yang harus digunakan. Faktor penyebab kesulitan siswa dalam tahap melaksanakan perencanaan penyelesaian masalah adalah karena siswa tidak tahu persamaan yang harus digunakan menyebabkan siswa kesulitan pada tahap melaksanakan rencana. Selain itu siswa kurang terampil dalam melakukan perhitungan. Faktor penyebab kesulitan siswa dalam tahap meninjau kembali adalah karena siswa kurang teliti dan tidak memeriksa kembali jawabannya

\section{REFERENSI}

Adegoke, B. A. (2011). Effect of Multimedia Instruction on Senior Secondary School Students' Achievment ini Physics. European Journal of Educational Studies, $3(3)$.

Azizah, R., Yuliati, L., \& Latifah, E. (2015). Kesulitan Pemecahan Masalah Fisika Siswa SMA. Jurnal Penelitian Fisika dan Aplikasinya (JFA), 5(2), 44-50.

Datur, I. S., Yulianti, L., \& Murti, N. (2016). Eksplorasi Kemampuan Pemecahan Masalah Siswa Fisika pada Materi Fluida Statis. Pros. Seminar Pend. IPA Pascasarjana UM, 1, 294-300.

Gumilang, D. T., Kriswandani, \& Mampouw, H. L. (2016). Analisis kemmpuan pemecahan masalah matematika berdasarkan langkah-langkah polya pada materi sritmetika sosial siswa kelas VII SMP N 1 Bringin. Jurnal Pendidikan Matematika FKIP-Universitas Kristen Satya Wacana Salatiga, 1, 1-20.

Hedge, B., \& Meera, B. (2012). How Do They Slove It? An Insight into the Learner's approach to the mechanism of problem solving. Physical Review Physics Education Research, 8(1), 1-9.

Rohmah, L., Handono, S., \& Yushardi. (2018). Analisis Kesalahan Siswa dalam Memecahkan Masalah Fisika Berdasarkan Polya pada Pokok Bahasan Fluida Statis di SMAN Jember. Jurnal Pembelajaran Fisika, 7(4), 328-333.

Saputri, A. A., \& Wilujeng, I. (2017). Developing Physics E-Scaffolding Teaching Media to Increase the EleventhGrade Students' Problem Solving Alibity and Scientific Attitude. International
Journal Of Enviromental \& Science Education, 12(4), 729-745. 